
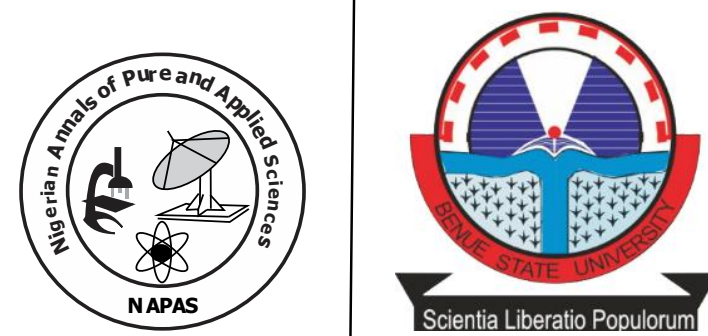

\title{
Radionuclide Content of Aerosols within the Lower Atmosphere of Major Towns in Plateau State, North Central Nigeria.
}

\author{
*Sombo, T., Entonu, S., Igbawua, T. and Shivil, J.T. \\ Department of Physics, \\ Federal University of Agriculture, Makurdi, Nigeria. \\ Corresponding Author: jtsombo@gmail.com
}

doi: https//doi.org/10.46912/napas.237

\begin{abstract}
Radioactivity analysis of aerosols within the lower atmosphere of some selected towns in Plateau state, North central Nigeria was carried out using Respirable Dust sampler (APM 460NL) and Gamma Ray Spectroscopy technique to ascertain their radiological safety and radiation dose to the general public. The mean mass concentration of fine $\left(\mathrm{PM}_{2.5}\right)$ and coarse $\left(\mathrm{PM}_{10}\right)$ aerosols were found to be 234.4 and $390.6 \quad\left({ }^{\mu g} / \mathrm{m}^{3}\right)$ respectively for Pankshin; 381.3 and $312.5 \quad\left(\mu g / \mathrm{m}^{3}\right)$ respectively for Shendam, and 208.3 and $250.0 \quad\left(\frac{\mu g}{\mathrm{~m}^{3}}\right)$ for Jos. The mean activity concentration of Potassium-
40, Radium-226 and Thorium-232 in the selected towns were found to be 510.82,52.16 and $29.76 \mathrm{~Bq} / \mathrm{kg}$
respectively. Average values of the following radiological parameter Da, AEDE, HEX and AGED were
$4.3439 \mathrm{nGy} / \mathrm{yr}, 0.0053 \mathrm{MSv} / \mathrm{yr}, 0.025 \mathrm{~Bq} / \mathrm{kg}$, and $30.3470 \mathrm{mSv} / \mathrm{yr}$ respectively. The activity
concentration of Potassium-40 was beyond the permissible limit at Shandan while that of Radium- 226
was beyond the set limit in Jos and Pankshin. The concentration of Thorium-232 in the study areas was
below permissible limit. Continuous exposure to these radionuclides and their progenies including their
synergetic effects with trace metals in the aerosols may pose several risk to public health. This work is
useful in regional environmental radiation monitoring and is part of efforts geared towards generating
baseline data for environmental radioactivity levels within North Central Nigeria.
\end{abstract}

Keywords: Air quality, Aerosols, Radionuclides, Public exposure, Environmental Radioactivity. 


\section{Introduction}

The quality of human health, nature and built environment around man depends largely on the quality of air in his environment (Rao and Rao, 1989). The quality is often reduced as a result of foreign materials (pollutants) in air. These pollutants are either gaseous or particulate in nature. The particulate pollutants (aerosols) consist of numerous chemicals that form particles and droplets of widely varying sizes with diverse effects on human health and environment (shah et al 1997). Aerosols of terrestrial origin are likely to contain significant amount of radionuclides, such as ${ }^{226} \mathrm{Ra},{ }^{232} \mathrm{Th}$ and ${ }^{40} \mathrm{~K}$ when significant amount of aerosols are inhaled, they remain lodged in human lungs causing continuous exposure via their decay process. The decay of these radionuclides emit radiations which have the potentials of causing breakage of bonds within cells leading to various health effects such as Lung cancer, Cataract, Erithema, Hematological depression, Birth defects and chromosome aberration (Ovwiri and Ononngbo,2012; Sombo et al 2014).

Air quality assessment (AQS) is an integral part of air quality monitoring system which provides data for evaluation of pollutants source contribution and fractions of the population experiencing pollution above specified limits (Shah et al.,1994). Similarly, environmental radioactivity monitoring is usually performed for the purpose of assessing radiations doses to the public from natural and artificial sources (UNSCEAR,2000).

There have been speculations that the concentration of aerosols in the lower atmosphere of cities is being elevated and the daily related emergency visits to hospitals and clinics can be correlated with the ambient aerosols concentrations (John et al, 2000 Ugwuanyi and Obi 2002) Recent research by Ugwuanyi et al.
(2006) and Tyovenda et al. (2016) supports this assertions that atmospheric aerosols contain hazardous trace metals and radionuclides in the fine and coarse domain which are capable of causing severe health effects especially when it enters the human body through inhalation of aerosol. This paper seeks to carry out the radioactivity analysis of aerosols in the lower atmosphere of some towns in Plateau State, North central Nigeria so as to ascertain the radiological safety level of aerosols in the lower atmosphere of the study area.

\section{Materials and Methods Study Area}

Plateau state is located in North Central geopolitical zone of Nigeria at an elevation of $1,280 \mathrm{~m}$, covering about 7,770 $\mathrm{km}^{2}$ of good agricultural land, joined with a distinct temperate climate (Ojo, 2016). It is bounded by latitudes $8^{0}$ $50^{\mathrm{I}} \mathrm{N}$ and $9^{0} 00^{\mathrm{I}} \mathrm{N}$, and longitude $9^{0} 45^{\mathrm{I}} \mathrm{E}$ and $9^{0}$ $50^{\mathrm{I}}$ E (Onwuka et al, 2013). Plateau state was created in 1976 with Jos as its capital. The origin of the name Plateau State was derived from Jos Plateau Highlands. The land features show many ridges, rough hills and rock formation. The dry season generally starts from November to April while the wet season starts from May to October, the cycle allows an average of six (6) months for growing season (Lee, 1972).Its soil composed of eroded gneiss rock formations, with granitic rock intrusions composed of massifs, and has various extinct volcanic cones bounded by basaltic drifts, especially the area around Panyam in the south and Vom and Miango in the west, including so many lakes (Jain, 2012). The tin and Ore fields of Plateau have been subjected to extensive mining activities and severe environmental degradation which in the last few decades (Mallo and Wazoh, 2014). 

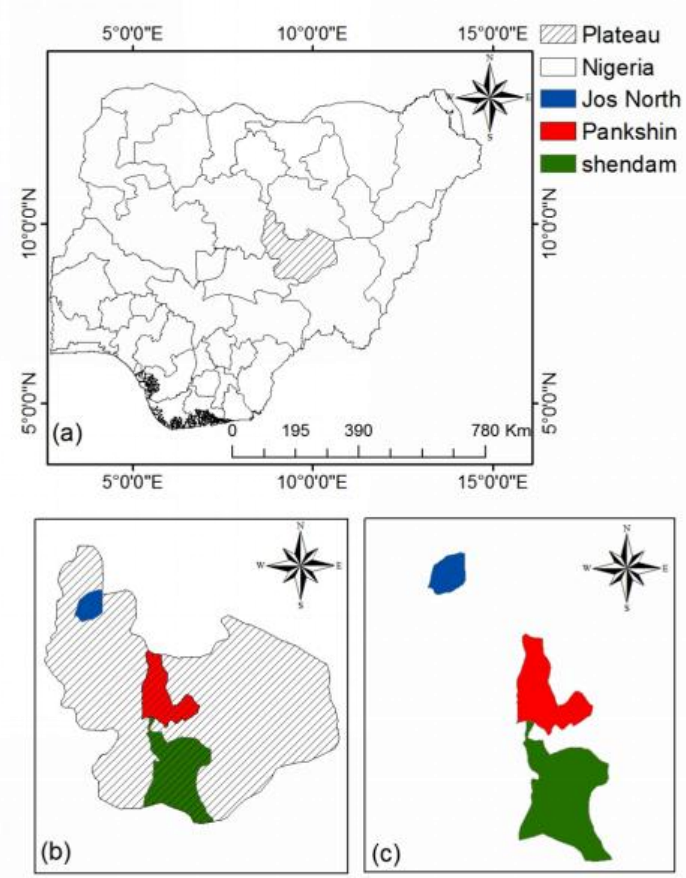

Figure 1: Map (a) Nigeria showing Plateau State, (b) Plateau State showing Local Government Areas (LGAs) where samples were taken and (c) LGAs where samples were taken.

\section{Materials and Methods}

Materials used in this work include Respirable Dust Sampler (APM 460 NL) and Gamma ray spectrometer method.

\section{Aerosol Sampling}

The Respirable Dust Sampler [APM 460 $\mathrm{NL}$ ] was placed on the elevated platform of about $1.5 \mathrm{~m}$ high situated $20 \mathrm{~m}$ from tall buildings and trees to avoid obstruction of the wind Marked and pre-weighed sample bottles were fixed under the conical hopper and filter paper were placed between the top filters adaptor assembly of the APM 460NL machine to collect fine and coarse aerosols. For an average sampling time of 8 hours, the mass of the coarse aerosols was measured using electronic weighing machine. The volume of sampled air was obtained from the flow meter reading and sampling time.

Mass concentration of coarse PM was calculated using National Environmental Engineering Research Institutes (NEERI) method; Volume of air sampled $V=\varphi \times t$ Where $V=$ Air volume sampled (m3), $\quad \varphi=$ Average air flow rate $\left(\mathrm{m}^{3} / \mathrm{min}\right)$ and $t=$ Sampling time (minutes)

The mass concentration of suspended particulate matter was estimated and reported to the nearest microgram per cubic meter as follows;

$$
\operatorname{PM}\left(\mu \mathrm{g} / \mathrm{m}^{3}\right)=\frac{\mathrm{M}_{2}-\mathrm{M}_{1}}{\mathrm{~V}} \mathrm{X} 10^{6}
$$

where $\mathrm{PM}=$ mass concentrations of suspended aerosols $\left(\mu \mathrm{g} / \mathrm{m}^{3}\right), \mathbf{M}_{1}=$ Initial mass of sample bottle $(\mathrm{g}), \mathrm{M}_{2}=$ final mass of sample bottle $(\mathrm{g})$, and $10^{6}=$ Conversion factor from gram to micrograms.

\section{Determination of Radiological Parameters}

The activity concentrations of Potassium$40\left({ }^{40} \mathrm{~K}\right)$, Radium-226 $\left({ }^{226} \mathrm{R}\right)$ and Thorium-232 $\left({ }^{232} \mathrm{Th}\right)$ were measured using gamma ray spectroscopy method. The energy calibration of the systems was carried out using a reference standard source prepared by the Radiochemical Center, Amersham-England. A $1.460 \mathrm{Mev}$ photo peak was used for the activity concentration measurement of ${ }^{40} \mathrm{~K}$ while a $1.120 \mathrm{Mev}$ photo peak from 214Bi and $0.911 \mathrm{Mev}$ photopeak from 288Ac were used for the activity concentration measurement of ${ }^{226} \mathrm{Ra}$ and ${ }^{232} \mathrm{Th}$ respectively. Each sample was counted for 25200 seconds after which the actual specific activity concentration of each radionuclide in the samples was determined using the following radiation factors 18.5, 12.3 and 15.4 for ${ }^{40} \mathrm{~K},{ }^{226} \mathrm{Ra}$ and ${ }^{232} \mathrm{Th}$ respectively .

Absorbed dose rate $\left(D_{a}\right)$, Annual effective dose rate $(A E D)$ and External hazards index $\left(H_{E X}\right)$ were calculated using equations (3), (4) and (5) respectively.

$D a\left(m G y h^{-1}\right)=0.462 A_{R a}+0.604 A_{T h}+0.0417 A_{k}$ (3) $A E D\left(\mu S v \cdot y^{-1}\right)=D_{a}\left(n G y \cdot h^{-1}\right) \times 8760 h \times 0.2 \times$ $0.7 S v \cdot G y^{-1} \times 10^{-3}$

$H_{E X}=\left[\frac{A_{R a}}{370}\right]+\left[\frac{A_{T h}}{256}\right]+\left[\frac{A_{k}}{4810}\right] \leq 1$

Where, Da is the absorbed dose in air, AED is the annual effective dose, $\mathrm{H}_{\mathrm{EX}}$ is the radiological hazard index, $\left[\mathrm{A}_{\mathrm{RA}}, \mathrm{A}_{\mathrm{Th}}\right.$ and $\mathrm{A}_{\mathrm{k}}$ are Specific concentrations of ${ }^{226} \mathrm{Ra},{ }^{232} \mathrm{Th}$ and ${ }^{40} \mathrm{~K}$ respectively.

Equations (6) was used to estimate the Annual Gonadal Equivalent Dose [AGED], Avwiri et al (2014).

$A G E D\left(m S v y^{-1}\right)=3.09 C_{R A}+4.18 C_{T h}+0.31 C_{k}$

Where, AEDE is the annual effective dose equivalent while $\mathrm{C}_{\mathrm{Ra}}, \mathrm{C}_{\mathrm{Th}}$ and $\mathrm{C}_{\mathrm{k}}$ are the activity concentrations of ${ }^{226} \mathrm{R},{ }^{232} \mathrm{Th}$ and ${ }^{40} \mathrm{~K}$ respectively.

\section{Results}

Results of this research work are presented in Tables 1 and Figure 1- 2(a,b,c,d). 
Table1: Mean activity concentration of ${ }^{226} \mathrm{R},{ }^{232} \mathrm{Th}$ and ${ }^{40} \mathrm{~K}$ in aerosols within Plateau State.

\begin{tabular}{|c|c|c|c|}
\hline Location & $\begin{array}{ll}{ }^{40} \mathrm{~K} & \text { Concentration } \\
(\mathrm{Bq} / \mathrm{Kg}) & \\
\end{array}$ & $\begin{array}{ll}{ }^{226} \mathrm{R} & \text { Concentration } \\
(\mathrm{Bq} / \mathrm{Kg}) & \\
\end{array}$ & $\begin{array}{ll}{ }^{232} \mathrm{Th} & \text { Concentration } \\
(\mathrm{Bq} / \mathrm{Kg}) & \end{array}$ \\
\hline Jos & $178.0447 \pm 2.9495$ & $46.9493 \pm 3.1965$ & $35.1512 \pm 1.1009$ \\
\hline Shendan & $994.6372 \pm 7.6688$ & $29.2884 \pm 4.7948$ & $31.0620 \pm 0.6291$ \\
\hline Pankshin & $359.7898 \pm 1.9842$ & $80.2333 \pm 0.8391$ & $23.0803 \pm 0.3932$ \\
\hline Mean & $510.8239 \pm 4.2008$ & $52.1570 \pm 2.935$ & $29.7645 \pm 0.7077$ \\
\hline
\end{tabular}

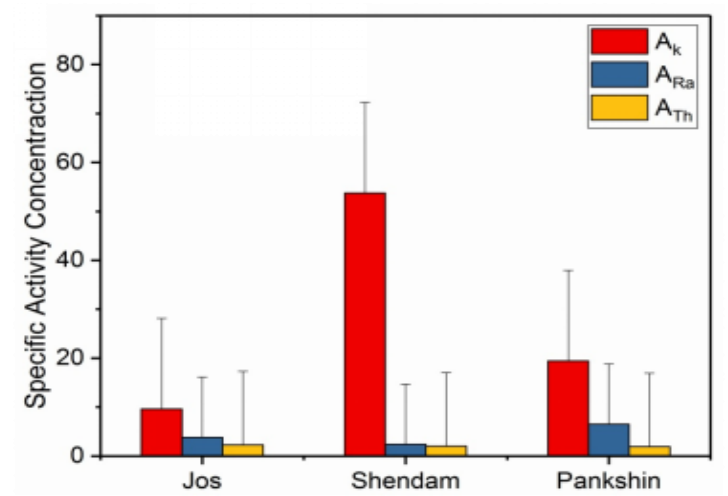

Figure 1 Specific Activity Concentration of Potassium-40, Ra224 and Th-232 in the study area.
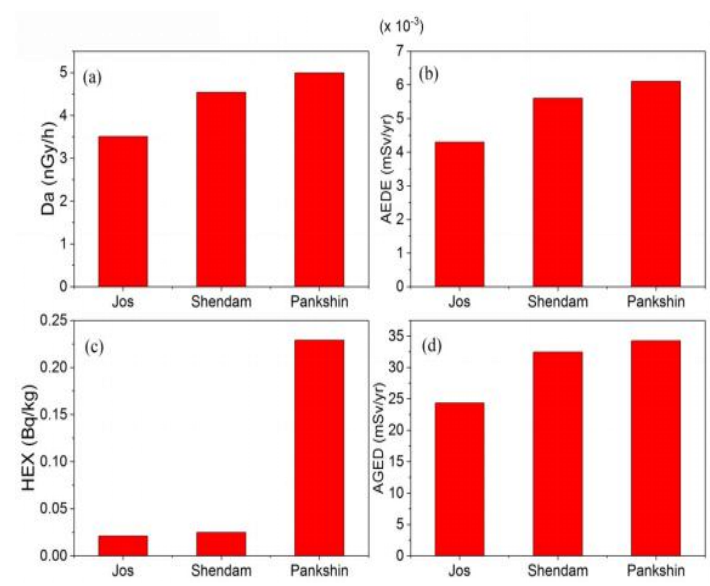

Figure 2 (a) Absorbed dose (Da) (b) Annual effective dose equivalent (AEDE) (c) Radiological hazard index (HEX) and (d) Annual gonadal equivalent dose (AGED)

\section{Discussion}

The study revealed that the activity concentrations of ${ }^{40} \mathrm{~K},{ }^{232} \mathrm{Th}$ and ${ }^{226} \mathrm{Ra}$ shown in Table 1 in the aerosols vary within the study areas and are below their respective world average values of 420,45 and $33 \mathrm{~Bq} / \mathrm{kg}$. The presence of traces of these radionuclides in aerosols may be due to their terrestrial abundance in surface soils within the region. The high value of ${ }^{40} \mathrm{~K}$ activity concentration recorded in Table (1) strongly suggests that the aerosols in the area contain some ores which belong to a group of minerals that consist of aluminum silicates of potassium. (Ajayi and Ibikunle, 2013).

The absorbed dose due to NORMS concentration in the soil ranged from 3.5050$4.9903 \mathrm{~Bq} / \mathrm{kg}$ with a mean value of $4.3439 \mathrm{nGy} / \mathrm{h}$ which is within the UNSCEAR (2000)
Permissible level of $59 \mathrm{nGy} / \mathrm{h}$. Though, the values vary from site to site due to difference in geographical and geochemical formations of the sites. The Annual Effective Dose Equivalent which is the product of equivalent dose $\mathrm{H}_{T}$ and tissue weighing factor $\mathrm{W}_{\mathrm{T}}$ was ranged from $0.0043-0.0061 \mu \mathrm{Sv} / \mathrm{yr}$ with a mean value of $0.0053 \mu \mathrm{Sv} / \mathrm{yr}$. This is found to be within the International Commission on Radiological Protection (ICRP, 1990) safety standard of $0.07 \mathrm{msv} / \mathrm{yr}$. The External Radiological Health Hazard index $\left(\mathrm{H}_{\mathrm{EX}}\right)$ was found in the ranges of 0.021-0.029 with mean value of 0.025 which is less than world average value. Finally, the Annual Gonadal Equivalent Dose (AGED) whose values have been associated with the effects of radiation on the bone marrow, bone surface cells and red blood cells (leading to leukemia) have mean value of $30.0 \mathrm{msv} / \mathrm{yr}$ which is less than the UNCEAR (2008) world average.

The result of the work strongly agrees with the published works from other mining areas in Nigeria such as the work of Augustine et al., (2014) who worked on the activity concentrations of natural radionuclides ${ }^{238} \mathrm{U},{ }^{232} \mathrm{Th}$ and ${ }^{40} \mathrm{~K}$ in soil samples from Gold mining areas in Itaguumodi, south-western Nigeria. Their research work revealed that the concentration of ${ }^{238} \mathrm{U},{ }^{232} \mathrm{Th}$ and ${ }^{40} \mathrm{~K}$ are $55.3 \pm 1.2,26.4 \pm 2.7$ and $505.1 \pm 7.1 \mathrm{BqKg}^{-1}$ respectively with the mean dosage of $81.3 \mu \mathrm{Sv}$.

The present work also agrees with the work of Ibrahim et. al, (2013) who carried out research on Assessment of radioactivity concentration in soil of some mining areas in central Nasarawa state, a neighbouring state that shares boundary with Plateau state (study area). The study revealed that the activity concentration of ${ }^{226} \mathrm{Ra},{ }^{232} \mathrm{Th}$ and ${ }^{40} \mathrm{~K}$ were $32.52 \pm 4.65$, $56.23 \pm 2.30$ and $403.96 \pm 7.29$ respectively with annual mean effective dose of $0.04 \pm 2.7 \mathrm{mSv} / \mathrm{yr}$. Further comparison with the works of other researchers in west-Africa such as Faann et al., (2016) on natural radioactivity levels of soils, rocks and water at mining concession of perseus gold mine and the surrounding towns in central Ghana shows that the activity concentrations of ${ }^{238} \mathrm{U}\left(65.1 \pm 2.2 \mathrm{BqKg}^{-1}\right),{ }^{232} \mathrm{Th}\left(71.8 \pm 2.2 \mathrm{BqKg}^{-1}\right)$ 
and ${ }^{40} \mathrm{~K}\left(1168.3 \mathrm{BqKg}^{-1}\right)$ and their radiological health hazard indices are higher than the values obtained in this present study.

The radiological parameters investigated in this study confirmed that the aerosols within the lower atmosphere of the study areas are safe with respect to Naturally Occurring Radionuclide Materials (NORMS) and may pose no significant effect on the inhabitant of the region.

\section{Conclusion}

The result of this study shows that there exist traces of radionuclide (226- $\mathrm{Ra}, 232-\mathrm{Th}$, and $40-\mathrm{K})$ but the concentrations are within acceptable limits. Although, the radioactivity level is low but continuous exposure to these radionuclide, their progenies and their synergetic effects with other constituents (trace metals) in aerosols may pose health risk to the public.

\section{Acknowledgement}

The authors are grateful to the management of Centre for Energy Research and Technology (CERT) Ahmadu Bellow University Zaria, for radiological analysis of our aerosol samples.

\section{References}

Augustine K.A., Adekunle K.B and Adeniyi C.A (2014). Determination of natural radioactivity and hazard in soil samples in and around gold mining area in Itagunmodi, south-western, Nigeria. Journal of Radiation Research and Applied Sciences. Vol. 7, 249 -255 .

Faann A., Adukpo O.K., Tettey-Larbi L., Lawluvi H., Kpeglo D.O., Darko E.O., EmiReynolds G., Awudu R.A., Kansaana C., Amoah P.A., Efa A.O., Ibrahim A.D., Agyeman B., Kpodzro R and Agyeman L (2016). Natural radioactivity levels in soils, rocks and water at a mining concession of persus gold mine and surrounding towns in central region of Ghana. Springer plus. Vol. 5: 98 .

Ibrahim U., Akpa T.C and Daniel I.H (2013). Assesment of Radioactivity Concentration in soil of some mining areas in Central Nasarawa State, Nigeria. Science World Journal Vol.8 (No 2): 7 - 12.
ICRP (1990). The Evaluation of Risk from radiation proceeding of international commission on Radiological Protection Publication, Pergamon press.

Jain, P, (2012) Jos Plateau, Encyclopedia Britannica, Online Encyclopedia 2018.

John A.C., Kuhibusch T. A. J Fissan (2000). PM sampling and characterization: Sampling of $\mathrm{PM}_{10}, \mathrm{PM}_{215}$ and $\mathrm{PM}_{1}$ and Chemical Analysis by Total Reflection X-ray Fluorescence Analysis. Journal of Aerosol, Vol.34 Suppl. 1 pp $192-200$.

Lee, V.H. (1972) Ecological aspects of the Jos Plateau, Nigeria, Bull.Wld Org. 46:641-644.

Mallo, S.J. \&Wazoh, H.N (2014) Reclamation of Abandoned mined-out Areas of BukuruRayfield, Journal of Environmental Science, toxicology \& Food Technology, 8(2):25-34.

Onwuka, S.U., Duluora, J.O., Okoye, C.O. (2013) Socio-Economic Impacts of Tin mining in Jos, Plateau State, Nigeria.International Journal of Engineering Science Invention, 2(7): 30-34

Ovwiri and Ononugbo [2012].Natural Radioactivity levelin surface soils of Ogba/Egbeme /Ndomi oil and Gas fields.Energy science and Technology.

Rao and Rao [1989]. Air pollution. Tata mcgraw.hill.publishing company Ltd. New delhi pp.-25

Shah J.J, Nagpa T Bradon[1997].urban Air management strategy in Asia-guide Book. The world Bank USA.PP17-21.

Sombo T., Ige T. A. and Agba E.H (2014). Mathematical modeling of the Effects of Gamma Irradiation on Dielectric Dispersion Properties of Bovine Liver Tissues at low and Radiofrequency. International Journal of Biophysics 5(1):12-17.

Tyovenda A. A, Ayua T.T. and Sombo T. (2016).Heavy metals concentration Analysis in Air Particulates of some Major Towns of Nasarawa State - Nigeria.Int. Res. J. Environmental Sc. Vol. 5(8), 22-28.

Ugwuanyi J.U, Agbende A.A. and Sombo T. (2006). PM Characterization in some major towns in Benue State - Nigeria. Journal of information Communication and Technology (JICCOTECH),2(1):183-187.

UNSCEAR, (2000) Sources and Effects of Ionizing radiation United Nationals Scientific Committee on Effects of Atomic Radiation Report to the General Assembly Vol. 1. 